\title{
Production and localisation of angiotensin II in the bovine early corpus luteum: a possible interaction with luteal angiogenic factors and prostaglandin F2 $\alpha$
}

\author{
S Kobayashi, B Berisha', W M Amselgruber², D Schams ${ }^{1}$ \\ and A Miyamoto \\ Department of Animal Science, Obihiro University of Agriculture and Veterinary Medicine, Obihiro 080-8555, Japan \\ ${ }^{1}$ Institute of Physiology, Technical University of Munich, D-80350 Freising-Weihenstephan, Germany \\ ${ }^{2}$ Department of Anatomy and Physiology, University of Hohenheim, D-70593 Stuttgart, Germany \\ (Requests for offprints should be addressed to A Miyamoto; Email: akiomiya@obihiro.ac.jp)
}

\begin{abstract}
The newly formed corpus luteum (CL) rapidly develops after ovulation and has the features of active vascularisation and mitosis of steroidogenic cells. These stage-specific mechanisms also may contribute to gain the function of prostaglandin F2 $\alpha$ (PGF2 $\alpha$ )-resistant CL at this stage. Recent studies suggest that the vasoactive peptide angiotensin II (Ang II) regulates luteal function. Thus, this study aimed to investigate (i) the expression of angiotensinconverting enzyme (ACE) mRNA by RT-PCR and the ACE protein expression by immunohistochemistry, (ii) the effects of angiogenic growth factors, basic fibroblast growth factor (bFGF) and vascular endothelial growth factor (VEGF), on the secretion of Ang II, PGF2 $\alpha$, progesterone and oxytocin (OT), and (iii) the effects of luteal vasoactive peptides (Ang II and endothelin-1 (ET-1)) or OT on the secretion of PGF2 $\alpha$, progesterone and OT from bovine early CL (days 3-4 of the oestrous cycle), and evaluate a possible interaction of these substances with PGF2 $\alpha$. The expression of mRNA for ACE was found in theca interna of mature follicle, early CL and endothelial cells from developing CL as well as pituitary and kidney, but granulosa cells of mature follicle were negative. The immunohistochemical analysis revealed that blood capil-
\end{abstract}

laries (endothelial cells) were stained for ACE, but luteal cells were negative in early CL. To examine the effects of substances on the secretory function of the CL, an in vitro microdialysis system was used as a model. The infusion of bFGF and VEGF stimulated Ang II and PGF2 $\alpha$ secretion as well as progesterone, but not OT secretion in early CL. The infusion of Ang II after PGF2 $\alpha$ infusion continued the stimulatory effect on progesterone and OT release within early CL until $3 \mathrm{~h}$ thereafter. However, the infusion of ET-1 alone had no effect on progesterone or OT release. The infusion of luteal peptides such as Ang II and OT stimulated PGF2 $\alpha$ secretion, whereas the infusion of ET-1 did not. In conclusion, the overall results of this study indicate that a functional angiotensin system exists on the endothelial cells of early CL, and that angiogenic factors bFGF and VEGF upregulate luteal Ang II and PGF2 $\alpha$ secretion, which fundamentally supports the mechanism of progesterone secretion in bovine early CL. This idea supports the concept that the local regulatory mechanism involved in active angiogenesis ensures the progesterone secretion in the developing CL in vivo.

Journal of Endocrinology (2001) 170, 369-380

\section{Introduction}

The new corpus luteum (CL) formed after ovulation rapidly develops within a few days. This process consists of highly active vascularisation and mitosis of steroidogenic cells in parallel. Such local mechanisms must be strictly regulated, and probably affect each other. It is well known that basic fibroblast growth factor (bFGF) (Gospodarowicz et al. 1986) and vascular endothelial growth factor (VEGF) (Ferrara \& Davis-Smyth 1997) stimulate the growth of new capillary vessels. Besides its angiogenic activity, bFGF stimulates progesterone secretion from bovine early
CL in vitro (Miyamoto et al. 1992). Also, the inhibition of VEGF bioactivity causes the suppression of CL angiogenesis and progesterone release (Ferrara et al. 1998, Fraser et al. 2000). Furthermore, bFGF increases prostaglandin F2 $\alpha$ (PGF2 $\alpha$ ) production in bovine luteal cells from the early luteal phase (Schams et al. 1995). Taken together, these angiogenic growth factors appear to upregulate both structure (angiogenesis) and function (secretion) of developing CL in vivo. This raises the possibility that an interaction among angiogenic growth factors, PGF2 $\alpha$ and progesterone plays an essential role in CL development. These stage-specific mechanisms 
also may contribute to gain the function of PGF2 $\alpha$ resistant $\mathrm{CL}$ at this stage.

A vasoactive peptide, angiotensin II (Ang II) that is converted from Ang I by angiotensin-converting enzyme (ACE), regulates oocyte maturation (Kuo et al. 1991), ovulation (Kuo et al. 1991) and steroidogenesis (Yoshimura et al. 1993). The localisation of ACE in bovine pulmonary endothelial cells (Ideishi et al. 1993) and the existence of Ang II receptor in bovine aortic endothelial cells (Tallant et al. 1997) have been reported. Furthermore, we recently showed that Ang II was converted from Ang I in microvascular endothelial cells from bovine CL, and that these cells have Ang II receptors (Hayashi et al. 2000). Additionally, Ang II has an inhibitory effect on progesterone release from bovine midcycle $\mathrm{CL}$, and this inhibitory effect was potentiated by PGF2 $\alpha$ (Hayashi \& Miyamoto 1999).

Several studies have reported that other luteal peptides such as oxytocin (OT) and endothelin-1 (ET-1) influence progesterone secretion in bovine CL in vitro (Miyamoto \& Schams 1991, Girsh et al. 1996a, Sakumoto et al. 1996, Miyamoto et al. 1997). OT increases the progesterone secretion from bovine CL throughout the luteal phase and this stimulatory effect is highest in early CL (Miyamoto \& Schams 1991). Furthermore, OT increases PGF2 $\alpha$ release by luteal cells compared with control cultures irrespective of day of oestrous cycle (Grazul et al. 1989). In contrast, ET-1 has been shown to inhibit progesterone release from bovine CL from the mid luteal phase of the oestrous cycle (Girsh et al. 1996a, Miyamoto et al. 1997), and the inhibitory effect of ET-1 was potentiated by PGF2 $\alpha$ (Miyamoto et al. 1997) as in the case for Ang II (Hayashi \& Miyamoto 1999). On the other hand, the tissue concentration of ET-1 in early CL is lower than that of other luteal phases (Girsh et al. 1996b). Thus, the local production and action of these peptides and PGF2 $\alpha$ in early CL appear to be quite different from those of the midcycle CL. This difference in local concentration of each product could be an important basis for the mechanisms for the regulation of PGF2 $\alpha-$ resistant $\mathrm{CL}$ in which angiogenesis is mostly active.

Thus, in this study, we aimed to investigate (i) the production and localisation of vasoactive peptide Ang II by using RT-PCR and immunohistochemistry, (ii) the effects of angiogenic growth factors, bFGF and VEGF, on the secretion of Ang II, PGF2 $\alpha$, progesterone and OT, and (iii) the effects of luteal vasoactive peptides (Ang II and ET-1) or OT on the secretion of PGF2 $\alpha$, progesterone and OT from bovine early CL, and evaluate a possible interaction of these substances with PGF2 $\alpha$.

\section{Materials and Methods}

\section{Collection of bovine tissues}

Entire reproductive tracts, pituitary and kidney tissue from Holstein cows were collected at a local slaughterhouse within 10-20 min of slaughter. The stage of the oestrous cycle was carefully defined by macroscopic observation of the uterus and ovaries (follicles and CL). Characteristics of the ovaries included size, colour, consistency, connective tissue and thickness of the endometrium, mucus, and absence of elongated early embryos. Ovaries from five cows with early CL (days 1-4 after oestrus), which were identified as stage I according to the criteria of Ireland $e t$ al. (1980), were collected. Follicles (>14 mm) were collected from six cows only after CL regression with signs of mucus production in the uterus and cervix, and were assumed to be preovulatory (follicular fluid oestradiol-17 $\beta$ concentrations of $>660 \mathrm{nmol} / \mathrm{l}$ ) and healthy (all follicles with a progesterone $>300 \mathrm{nmol} / 1$ follicular fluid were excluded). For the RNA extraction, the follicles were taken from the ovary. The surrounding tissue (theca externa) was removed with forceps under a stereomicroscope. After aspiration of follicular fluid, follicles were bisected and the inside wall was gently scraped and flushed with Ringer's solution (Fresenius AG, St Wendel, Germany) to remove the granulosa cells. All tissues were frozen rapidly in liquid nitrogen, and then stored at $-80{ }^{\circ} \mathrm{C}$ until processed for studies of gene expression. Luteal tissue was immersionfixed immediately after collection. For the microdialysis study, the ovaries were washed several times with sterile saline solution $(0.9 \% \mathrm{NaCl})$ and transported to the laboratory in sterile saline solution containing $60 \mathrm{mg} / \mathrm{l}$ penicillin and $100 \mathrm{mg} / 1$ streptomycin at $37^{\circ} \mathrm{C}$.

\section{Culture of microvascular endothelial cells}

Cytokeratin-negative endothelial cells, type 3, derived from the microvascular bed of the developing bovine CL were used, and cultured as described (Okuda et al. 1999). These cytokeratin-negative cells are known to occur with the form of a cobblestone appearance. Only the cells at 11 passages were used in the present study.

\section{$R N A$ isolation and RT-PCR}

Total RNA from bovine tissues (CL, theca interna, granulosa cells, pituitary, kidney and endothelial cells) was isolated by the single-step method of Chomczynski \& Sacchi (1987) using Trizol reagent (Gibco-BRL, Eggenstein, Germany) and spectroscopically quantified at $260 \mathrm{~nm}$. Aliquots were subjected to $1 \%$ denaturing agarose gel electrophoresis and ethidium bromide staining to verify the quantity and quality of RNA. The RNA yield was then either immediately subjected to RT-PCR or stored at $-80{ }^{\circ} \mathrm{C}$ until analysis.

Two micrograms total RNA were used to generate single-strand cDNA in a $60 \mu \mathrm{l}$ reaction mixture as described previously (Berisha et al. 2000a). The resulting cDNA templates were subjected to PCR amplification. Conditions for enzymatic amplification were optimised for each PCR as follows. The ACE contained $10 \mathrm{mmol} / 1$ 
Tris- $\mathrm{HCl}\left(\mathrm{pH} 8 \cdot 8\right.$ ), $50 \mathrm{mmol} / 1 \mathrm{KCl}, 1.5 \mathrm{mmol} / 1 \mathrm{MgCl}_{2}$, $0.1 \%$ Triton $\mathrm{X}-100,0.6 \mu \mathrm{mol} / \mathrm{l}$ of each primer, and 0.5 units of the thermostable polymerase PrimeZyme (Biometra, Göttingen, Germany) to $5 \mu \mathrm{l}$ cDNA (final volume $25 \mu \mathrm{l}$ ). The ubiquitin PCR was performed under the same conditions as those for ACE, but a higher concentration of primer $(1.5 \mu \mathrm{mol} / \mathrm{l})$ was used. On the basis of optimisation of temperature, amplification of ACE analysis consisted of one denaturing step at $94^{\circ} \mathrm{C}$ for 2 min, followed by 35 cycles at $94{ }^{\circ} \mathrm{C}$ for $45 \mathrm{~s}$ and at $64{ }^{\circ} \mathrm{C}$ for $45 \mathrm{~s}$. One additional elongation step was carried out at $72{ }^{\circ} \mathrm{C}$ for $2 \mathrm{~min}$. Amplification of the housekeeping gene consisted of one denaturing step at $94{ }^{\circ} \mathrm{C}$ for $2 \mathrm{~min}, 22$ cycles at $94{ }^{\circ} \mathrm{C}$ for $45 \mathrm{~s}, 55^{\circ} \mathrm{C}$ for $45 \mathrm{~s} ; 72{ }^{\circ} \mathrm{C}$ for $45 \mathrm{~s}$ and one additional elongation at $72{ }^{\circ} \mathrm{C}$ for $2 \mathrm{~min}$.

To determine the optimal quantity of reverse transcript needed for PCR and to verify that the cDNA product was dependent on the amount of transcript used, varying quantities of transcript template were used in the PCR reaction process. The RT-PCR product from $3 \mu \mathrm{l}$ cDNA was within the exponential phase of PCR reaction (plateau phase was avoided) and produced a visible band. To exclude the possibility of amplification of genomic DNA, all experiments included reactions in which the RT enzyme or cDNA template was omitted. As a negative control, water was used instead of RNA for the RT-PCR to exclude any contamination from buffers and tubes. The primers were designed by using the European Molecular Biology Laboratory (EMBL) database, or were used as described elsewhere and were commercially synthesised (Amersham-Pharmacia, Freiburg, Germany). The primers were as follows: ACE forward 5'-ATCCCGGAATTA TCAGGACC- $3^{\prime}$ and reverse 5'-AGGGTGCCACCA AGTCATAG-3' (EMBL Ac. no. AJ309016) and ubiquitin forward $5^{\prime}$-ATGCAGATCTTTGTGAAGAC- ${ }^{\prime}$ and reverse $5^{\prime}-$ TTCAGGAGCACACTGGAGTG-3'. The predicted sizes of the resulting RT-PCR products were $365 \mathrm{bp}$ for ACE and 189 and 417 bp for ubiquitin respectively, corresponding to identical multimeric gene cassettes.

Aliquots of the PCR reaction products $(5 \mu \mathrm{l})$ were added to $1 \mu \mathrm{l}$ bromophenol blue glycerine and fractionated by electrophoresis through a $1.5 \%$ agarose gel containing ethidium bromide in a constant $60 \mathrm{~V}$ field. To determine the length of the RT-PCR products, a mass ladder and $100 \mathrm{bp}$ marker were used. The resultant band intensities were scanned by a video documentation system (Amersham-Pharmacia) and analysed with the Image Master ID program (Amersham-Pharmacia). To verify each PCR product, double-strand sequencing was performed directly or after subcloning (TopLab, Munich, Germany).

\section{Fixation of CL tissue for immunohistochemistry}

The CL were dissected into $0.5 \mathrm{~cm}$ thick tissue slices, immersion-fixed in Bouin's solution for $12 \mathrm{~h}$, dehydrated in a graded series of ethanol, cleared in xylene and embedded in paraffin wax using conventional procedures. Serial sections of $5 \mu \mathrm{m}$ thickness were cut on a microtome (Leitz, Wetzler, Germany) and processed for immunohistochemistry.

\section{Tissue preparation and immunohistochemistry}

For the histological investigations, early CL from five cows, after collecting the small section for RNA extraction, were fixed via immersion with methanol/glacial acid $(2 / 1 \mathrm{v} / \mathrm{v})$ or Bouin's solution for ACE immunohistochemistry. After $12 \mathrm{~h}$ fixation, tissues were dehydrated in a graded series of ethanol, cleared in xylene and embedded in paraffin wax using conventional procedures. Serial sections of $5 \mu \mathrm{m}$ thickness were cut on a Leitz microtome and processed for immunohistochemistry. Localisation of ACE was performed according to the avidin-biotin-peroxidase complex method (Hsu et al. 1981). The sections were deparaffinised, rehydrated and treated for 30 min with $1 \%$ hydrogen peroxide in methanol to block endogenous peroxidase activity. After three washing steps in PBS ( $\mathrm{pH} 7 \cdot 4$ ), rabbit serum (DAKO, Hamburg, Germany) was used in 1:10 dilution for $30 \mathrm{~min}$ to prevent the non-specific binding of the antibodies. Overnight incubation with the primary antibody from chicken against rabbit lung ACE (Biotrend, Cologne, Germany; dilution 1:500) in a humid chamber at $4{ }^{\circ} \mathrm{C}$ followed. The antibody strongly cross-reacts with bovine, pig and human ACE. On the next day the slides were washed three times again with PBS and incubated for $30 \mathrm{~min}$ with a biotinylated goat anti-rabbit or rabbit anti-chicken serum IgG as the second antibody (1:400). A further $30 \mathrm{~min}$ later, after building the streptavidin-biotinhorseradish-peroxidase complex, peroxidase staining was performed with 3,3'-diaminobenzidine (DAB).

The specificity of the staining reaction was proved by serial dilution of the primary antigen, which resulted in a gradual decrease in intensity. Finally, all specimens were counterstained with haematoxylin and mounted with DePeX (Serva, Heidelberg, Germany) for light microscope examination.

The specificity of the immunocytochemical reactions was assessed by (i) replacement of the primary antibodies with buffer, (ii) their substitution with non-immune goat $\operatorname{IgG}(1: 10$ diluted), and (iii) incubation with DAB reagent alone to exclude the possibility of non-suppressed endogenous peroxidase activity. Lack of detected staining of tissue elements in the controls demonstrated the specificity of the reactions.

\section{Microdialysis system (MDS) in vitro}

The MDS of the bovine CL in vitro has been previously described in detail (Miyamoto \& Schams 1991). Eight different CL were used for the experiment on angiogenic growth factors. In other experiments, four to seven 
different CL in each experimental group were used. In brief, CL of the early luteal phase having diameters of $0 \cdot 8-1 \cdot 0 \mathrm{~cm}$ were isolated from the ovary, and divided into halves. The surrounding stromal tissue of each piece was then removed. Two capillary dialysis membranes (Fresenius SPS 900 Hollow Fibers, cut-off molecular mass $1000 \mathrm{kDa}, 0.2 \mathrm{~mm}$ diameter, $5 \mathrm{~mm}$ long; Fresenius AG) with each end glued to a $4.5 \mathrm{~cm}$ long piece of Silastic tubing (internal diameter $0.3 \mathrm{~mm}$ ) were implanted into each half of the CL at least a $5 \mathrm{~mm}$ distance between dialysis membranes. Thus, four membranes were implanted in each CL. One of the four dialysis membranes was used for a control and the other three were used for the infusion of stimulants. For infusion, one end of the tube was connected to a multiple-line peristaltic pump (IPC-24; Ismatec SA, Zurich, Switzerland) and the other was routed to a multiple-line fraction collector. The prepared luteal pieces were then placed in organ culture chambers (modified 2070 Tube; Falcon, Franklin Lakes, NJ, USA) that were filled with $50 \mathrm{ml} \mathrm{M199} \mathrm{(Sigma}$ Chemical Co., Deisenhofen, Germany) containing Eagle's salts, $10 \mathrm{mmol} / 1 \quad \mathrm{NaHCO}_{3}, \quad 365 \mathrm{mg} / \mathrm{l}$ L-glutamine, $25 \mathrm{mmol} / 1$ Hepes, $5 \mathrm{~g} / 1 \mathrm{BSA}, 60 \mathrm{mg} / 1$ penicillin, $100 \mathrm{mg} / 1$ streptomycin, $56 \mathrm{mg} / 1$ ascorbic acid, and $2 \mathrm{mg} / 1$ amphotericin $\mathrm{B}$ at $\mathrm{pH} 7 \cdot 4$ maintained in a water bath at $38^{\circ} \mathrm{C}$. The luteal pieces were perfused with Ringer's solution at a flow rate of $3.0 \mathrm{ml} / \mathrm{h}$ throughout the experiments.

In the experiment of angiogenic growth factors, fractions of the perfusate after a $3 \mathrm{~h}$ pre-perfusion were collected every $2 \mathrm{~h}(6 \mathrm{ml}$ per fraction) up to $10 \mathrm{~h}(0 \mathrm{~h}$ corresponds to the end of the pre-perfusion). Bovine bFGF (7.5 nmol/1; Boehringer Mannheim GmbH, Mannheim, Germany) or human VEGF (5 nmol/1; Pepro Techec Ltd, London, UK) were infused during $2-4 \mathrm{~h}$.

In other experiments, fractions of the perfusate after a $3 \mathrm{~h}$ pre-perfusion were collected every $30 \mathrm{~min}(1.5 \mathrm{ml}$ per fraction) up to $5 \mathrm{~h}$. The collected samples were stored at $-20{ }^{\circ} \mathrm{C}$ until hormone determination. After progesterone concentration was directly measured, the fractions were pooled (among $0-1 \mathrm{~h}, 1-1 \cdot 5 \mathrm{~h}, 1 \cdot 5-2 \mathrm{~h}, 2-3 \cdot 5 \mathrm{~h}$ and $3 \cdot 5-5 \mathrm{~h}$ ) depending on the experimental design for the purpose of desalting and concentrating the peptides, in order to reduce the number of samples. This step was needed to extract and concentrate OT in the samples that enabled us to determine the concentration by enzyme immunoassay (EIA). Consequently, for statistical analysis ten samples (every hour) were processed for progesterone secretion, while five samples (pooled fractions) were processed for OT, as described below.

Four substances were infused: PGF2 $\alpha$ (Sigma), ET-1, Ang II, and OT (all purchased from Peptide Institute Inc., Osaka, Japan). All were diluted in Ringer's solution to obtain the required final concentrations $(10 \mu \mathrm{mol} / 1$ for PGF2 $\alpha$ and OT, $0 \cdot 1 \mu \mathrm{mol} / 1$ for ET-1, and 10 or $1 \mu \mathrm{mol} / 1$ for Ang II). PGF2 $\alpha$ was infused between 1 and $1.5 \mathrm{~h}$, and
ET-1 or Ang II was infused between 1.5 and $2 \mathrm{~h}$. To determine whether an interaction between PGF2 $\alpha$ and OT had an effect on progesterone release, PGF2 $\alpha$ was first infused for $30 \mathrm{~min}(1-1 \cdot 5 \mathrm{~h})$, and then OT was infused for the next $30 \mathrm{~min}(1 \cdot 5-2 \mathrm{~h})$. Then the experiment was repeated but with the order of infusion reversed (OT infusion from 1 to $1.5 \mathrm{~h}$ followed by PGF2 $\alpha$ infusion from 1.5 to $2 \mathrm{~h}$ ). The transfer capacity of the microdialysis membrane was about $0 \cdot 1 \%$ for bFGF, VEGF, OT, ET-1, and Ang II, and about 1\% for progesterone and PGF $2 \alpha$. These values of transfer capacity were determined according to the method of Jarry et al. (1990). The concentrations of the infused substances were chosen based on both of the above transfer capacities, the preliminary experiment, the previous results for bFGF (Miyamoto et al. 1992), OT (Miyamoto \& Schams 1991), ET-1 (Miyamoto et al. 1997) and Ang II (Hayashi \& Miyamoto 1999), and basal release of each substance in this study.

\section{PGF2a extraction}

The volumes of perfusate samples were adjusted with Ringer's solution to $6 \mathrm{ml}$ in the experiment on growth factors and to $5 \mathrm{ml}$ in the other experiments. These pooled fractions were adjusted to $\mathrm{pH} 3.5$ with acetic acid and extracted using diethyl ether as described previously (Acosta et al. 1998). The residue was dissolved in $200 \mu \mathrm{l}$ assay buffer for the steroid and PGF2 $\alpha$ EIA $(40 \mathrm{mmol} / 1$ PBS, $0 \cdot 1 \%$ BSA, $\mathrm{pH} 7 \cdot 2$ ). The samples were concentrated 15- to 30-fold as a result of the process. To estimate the recovery rate in the MDS perfusate, $4 \mathrm{pmol} / 1$ PGF2 $\alpha$ were added to Ringer's solution, and the obtained value was $61 \%$.

\section{Extraction of peptides}

After the diethyl ether extraction, the remaining Ringer's solution (5 or $6 \mathrm{ml}$ ) was used for the extraction of peptides. BSA was added to the samples to a final concentration of $1 \mathrm{mg} / \mathrm{ml}$ and then the samples were adjusted to $\mathrm{pH} 2.5$ with acetic acid. The samples were then applied to a Sep-Pak C18 Cartridge (Waters, Millford, MA, USA) as described previously (Miyamoto et al. 1997). The residue was dissolved in $300 \mu \mathrm{l}$ assay buffer for peptide EIA (42 mmol/1 $\mathrm{Na}_{2} \mathrm{HPO}_{4}, 8 \mathrm{mmol} / 1 \quad \mathrm{KH}_{2} \mathrm{PO}_{4}, 20 \mathrm{mmol} / 1$ $\mathrm{NaCl}, 4.8 \mathrm{mmol} / 1$ EDTA, 0.05\% BSA, pH 7.5). The samples were concentrated $7 \cdot 5$ - to 20 -fold as a result of the process. To estimate the recovery rate in the MDS perfusate, OT, ET-1 and Ang II were added to Ringer's solution (50, 100, and $10 \mathrm{pmol} / 1$ respectively), and the obtained values were 73, 62 and $88 \%$ respectively. However, since the ET-1 concentration was too low to detect with an enrichment rate of $7 \cdot 5$ - to 20 -fold, to estimate the baseline ET-1 concentration $(0-1 \mathrm{~h})$, the fractions between $0-1 \mathrm{~h}$ in another experiment from four lines implanted in single CL were pooled to $10 \mathrm{ml}$ for six CL 
and then extracted, and the samples for ET-1 determination were concentrated 100 -fold as a result of the process.

\section{Hormone determination}

Progesterone, PGF2 $\alpha$, OT, ET-1 and Ang II concentrations were determined in the perfusate fractions from the MDS with second-antibody EIAs that were based on a competitive assay using horseradish peroxidase-labelled progesterone and PGF2 $\alpha$ or biotin-labelled peptides as tracers.

Concentrations of progesterone were assayed directly as described in detail earlier (Miyamoto et al. 1992). The standard curve of progesterone ranged from 0.16 to $160 \mathrm{nmol} / 1$, and the $\mathrm{ED}_{50}$ of the assay was $5.7 \mathrm{nmol} / \mathrm{l}$. The intra- and interassay coefficient of variation (CV) values were on average 6.2 and $9.3 \%$ respectively. The EIA for PGF2 $\alpha$ was carried out as described previously (Miyamoto et al. 1995). The standard curve of PGF2 $\alpha$ ranged from 55 to $5650 \mathrm{pmol} / 1$, and the $\mathrm{ED}_{50}$ of the assay was $1000 \mathrm{pmol} / \mathrm{l}$. The intra- and interassay $\mathrm{CV}$ values were on average $7 \cdot 8$ and $11.5 \%$ respectively. The EIAs for OT and ET-1 were conducted as described previously (Miyamoto et al. 1997). The standard curve of OT ranged from 1.6 to $200 \mathrm{pmol} / 1$, and the $\mathrm{ED}_{50}$ of the assay was $21 \mathrm{pmol} / \mathrm{l}$. The intra- and interassay CV values of the OT assay were on average 6.2 and $8.6 \%$ respectively. The standard curve of ET-1 ranged from 3.9 to $2000 \mathrm{pmol} / \mathrm{l}$, and the $\mathrm{ED}_{50}$ of the assay was $180 \mathrm{pmol} / \mathrm{l}$. The intra- and interassay $\mathrm{CV}$ values of the ET-1 assay were on average 8.7 and $12.6 \%$ respectively. The EIA for Ang II used rabbit antiserum raised against human Ang II as described in detail earlier (Hayashi \& Miyamoto 1999). The standard curve of Ang II ranged from $2 \cdot 3$ to $9560 \mathrm{pmol} / 1$ and the $\mathrm{ED}_{50}$ of the assay was $105 \mathrm{pmol} / \mathrm{l}$. The intra- and interassay CV values were on average 6.4 and $8.7 \%$ respectively. The cross-reactivities of Ang II antibody with Ang I, Ang II, Ang III and renin substrate were 10, 100, 50 and $5 \%$ respectively.

\section{Statistical analysis}

The mean hormone (progesterone, PGF2 $\alpha$, OT, ET-1 and Ang II) concentrations in the first $2 \mathrm{~h}$ (growth factors) or $1 \mathrm{~h}$ (others) fraction were used to calculate the individual baseline, because of a large variation in the basal concentrations of each hormone released into the MDS lines implanted in the different CL (progesterone 4.8-39.4 nmol/1, OT $0 \cdot 8-30 \cdot 2 \mathrm{pmol} / 1$, PGF2 $\alpha$ 13.6$85.9 \mathrm{pmol} / \mathrm{l}$, ET-1 0.03-0.06 pmol/1 and Ang II 4.5$38.4 \mathrm{pmol} / \mathrm{l})$. All hormone concentrations were expressed as a proportion of this individual baseline. This treatment enables an evaluation of relative changes of hormonal values between the different CL. The change in hormonal release after substance infusions was tested based on individual time points throughout the experiment as compared with the value at the same time point in the control. The change in hormone release by treatment was tested as compared with the value during the same time period in the control throughout the experiment $(1-1.5 \mathrm{~h}$, $1 \cdot 5-2 \mathrm{~h}, 2-3 \cdot 5 \mathrm{~h}$, and $3 \cdot 5-5 \mathrm{~h}$ ). Means were analysed by ANOVA followed by the Tukey-Kramer test as a multiple comparison test. For the figures of MDS data, all hormone concentrations in the fractions were then expressed as a percentage of this individual baseline. The significance of the difference is shown only for the experimental groups where the values were significantly higher than those in the control group at the same time period. The absolute concentrations of each hormone during the first 1 or $2 \mathrm{~h}$ (baseline) of an experiment are given in the figure legends.

\section{Results}

\section{Expression of $m R N A$ for $A C E$}

The RT-PCR product of ACE (partial sequence) showed $82 \%$ homology to the known human genes (EMBL Accession no. P12821) after sequencing. A specific transcript for ACE was detected in pituitary and kidney as well as the theca interna, early CL and endothelial cells from developing CL. However, the expression of ACE mRNA was not observed in granulosa cells (Fig. 1a). To confirm the integrity of the mRNA templates and RT-PCR protocol, the housekeeping gene ubiquitin was examined in all samples (Fig. 1b).

\section{Immunohistochemical localisation of ACE in bovine early $C L$}

The histological evaluation revealed that blood vessels selectively show a strong positive reaction for ACE. At the cellular level, ACE immunostaining is thereby restricted to the endothelial cells (Fig. 2A). Higher magnification demonstrates particular intense staining of the cell membrane (Fig. 2B). Specificity of the ACE immunostaining was confirmed by replacement of the primary antibody by non-immune serum (Fig. 2C).

\section{Basal substance release of microdialysed early CL in vitro}

Absolute concentrations of each substance in the MDS perfusate during basal release were $17 \cdot 1 \pm 0.6 \mathrm{nmol} / 1$ (S.E.M.) for progesterone, $8.8 \pm 0.7 \mathrm{pmol} / 1$ for Ang II, $0 \cdot 04 \pm 0.004 \mathrm{pmol} / 1$ for ET-1, $29 \cdot 4 \pm 4 \cdot 0 \mathrm{pmol} / 1$ for PGF2 $\alpha$ and $7 \cdot 1 \pm 0 \cdot 8 \mathrm{pmol} / 1$ for OT.

\section{Effects of growth factors on hormone release}

The infusion of bFGF and VEGF for $2 \mathrm{~h}$ stimulated progesterone, PGF2 $\alpha$ and Ang II secretion during infusion but had no effect on OT secretion (Fig. 3). 


\section{(a) ACE (365 bp)}

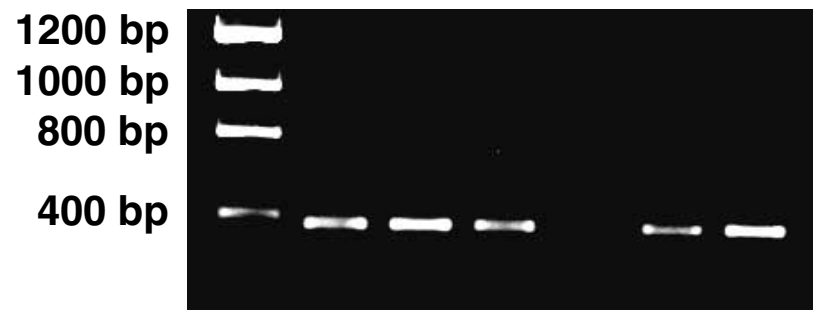

(b) Ubiquitin (189+417 bp)

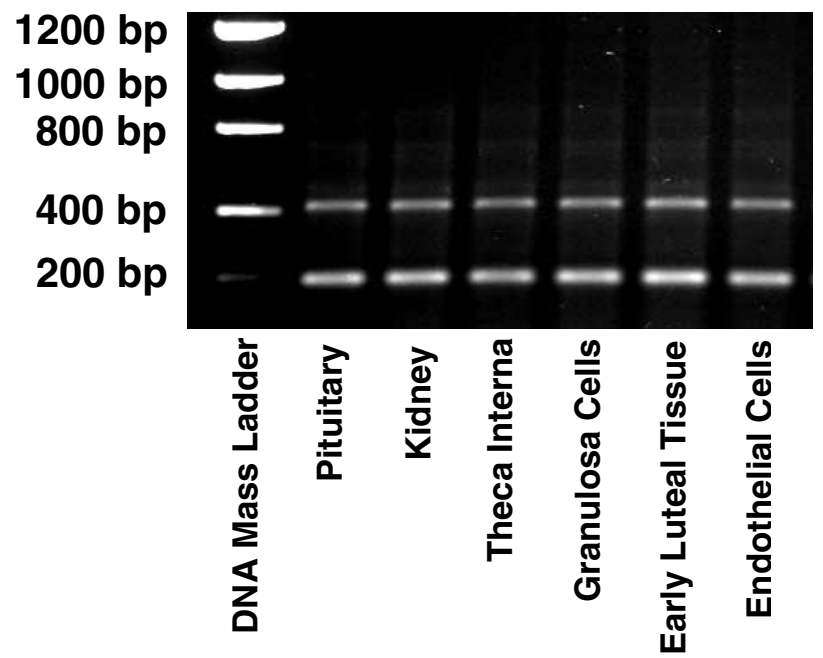

Figure 1 Specific RT-PCR products for (a) ACE (365 bp) and (b) ubiquitin $(189+417 \mathrm{bp})$ from bovine pituitary, kidney, theca interna tissue, granulosa cells, early luteal tissue and endothelial cells from developing CL, and a DNA mass ladder (1200, 800, 400 and $200 \mathrm{bp}$ ), separated by agarose gel electrophoresis.

Interaction of Ang II with PGF2a on progesterone and OT release

The infusion of Ang II at both 1 and $10 \mu \mathrm{mol} / 1$ significantly increased progesterone release $(P<0 \cdot 05$; Fig. 4). Ang II $(1 \mu \mathrm{mol} / \mathrm{l})$ stimulated progesterone release to $140 \%$ during infusion only (Fig. 4), while Ang II $(10 \mu \mathrm{mol} / \mathrm{l})$ stimulated progesterone release during and after infusion (Fig. 4). The infusion of Ang II $(10 \mu \mathrm{mol} / \mathrm{l})$ after PGF2 $\alpha$ infusion maintained the increased progesterone release between 160 and $250 \%$ during the experimental period $(P<0 \cdot 05 ;$ Fig. 4). In contrast, an interaction of Ang II $(1 \mu \mathrm{mol} / \mathrm{l})$ and PGF2 $\alpha$ was not observed on the progesterone release (Fig. 4). Although Ang II (1 $\mu \mathrm{mol} / 1)$ did not stimulate $\mathrm{OT}$ release from the CL (Fig. 5), Ang II $(10 \mu \mathrm{mol} / \mathrm{l})$ significantly stimulated it $(P<0 \cdot 05$; Fig. 5). Furthermore, the infusion of Ang II $(10 \mu \mathrm{mol} / \mathrm{l})$ after PGF2 $\alpha$ infusion maintained the increased OT release between 400 and $600 \%$ during the experimental period $(P<0 \cdot 05$; Fig. 5).
Interaction of ET-1 with PGF2a on progesterone and OT release

The infusion of ET-1 had no effect on progesterone or OT release (Figs 4 and 5). When ET-1 was infused after PGF2 $\alpha$ infusion, progesterone release was slightly stimulated $(P<0 \cdot 05$; Fig. 4$)$, but this stimulatory effect was not different from that of PGF2 $\alpha$ alone. In contrast to progesterone release, OT release was increased to around 400\% by the infusion of ET-1 after PGF2 $\alpha$, and this concentration was maintained throughout the experimental period $(P<0 \cdot 05$; Fig. 5).

\section{Interaction of OT with PGF2a on progesterone release}

The infusion of OT stimulated progesterone release between 170 and 195\% only during the infusion period $(P<0 \cdot 05$; Fig. 6). There was no clear interaction of OT with PGF2 $\alpha$ on the progesterone release (Fig. 6).

\section{Effect of luteal peptides on PGF2a release}

The infusion of ET-1 had no effect on PGF2 $\alpha$ release (Fig. 7). However, the infusion of Ang II stimulated PGF2 $\alpha$ secretion $(P<0.05$ for $1 \mu \mathrm{mol} / 1$ and $P<0.01$ for $10 \mu \mathrm{mol} / 1$; Fig. 7). The infusion of OT weakly stimulated PGF2 $\alpha$ release $(P<0 \cdot 05$; Fig. 7$)$.

\section{Discussion}

The present study provides direct evidence that the endothelial cell is the only site of Ang II production in the bovine early CL. The MDS study also showed that angiogenic growth factors bFGF and VEGF stimulate Ang II, PGF $2 \alpha$ and progesterone secretion from bovine early $\mathrm{CL}$ in vitro. Furthermore, luteal peptides such as Ang II and OT also stimulated PGF2 $\alpha$ secretion, and Ang II together with PGF2 $\alpha$ highly stimulated progesterone secretion. The results of this study, therefore, suggest that the interaction of PGF2 $\alpha$ and Ang II, the productions of which are upregulated by angiogenic factors, ensures the mechanisms of progesterone production in the developing CL.

It is well known that bFGF and VEGF stimulate neovascularisation (Gospodarowicz et al. 1986, Ferrara \& Davis-Smyth 1997). The present MDS study shows that these growth factors are also capable of stimulating PGF2 $\alpha$ and Ang II secretion as well as progesterone, but not OT production in the bovine early CL (Fig. 8). The expression of bFGF mRNA (Stirling et al. 1991) and the production of bFGF peptide have been shown in bovine (Gospodarowicz et al. 1985) and ovine (Grazul-Bilska et al. 1992) CL. The specific binding sites for bFGF have also been observed in cultured bovine luteal cells throughout the oestrous cycle (Schams et al. 1993). Importantly, the 
infusion of bFGF stimulated progesterone secretion from bovine CL in the MDS (Miyamoto et al. 1992, the present study), whereas bFGF had no effect on the progesterone secretion in bovine luteal cell culture (Miyamoto et al. 1992). Under the culture condition, cells are isolated and without almost any cell-to-cell contact, while cell-to-cell contact exists in the experiment with MDS. This raises the
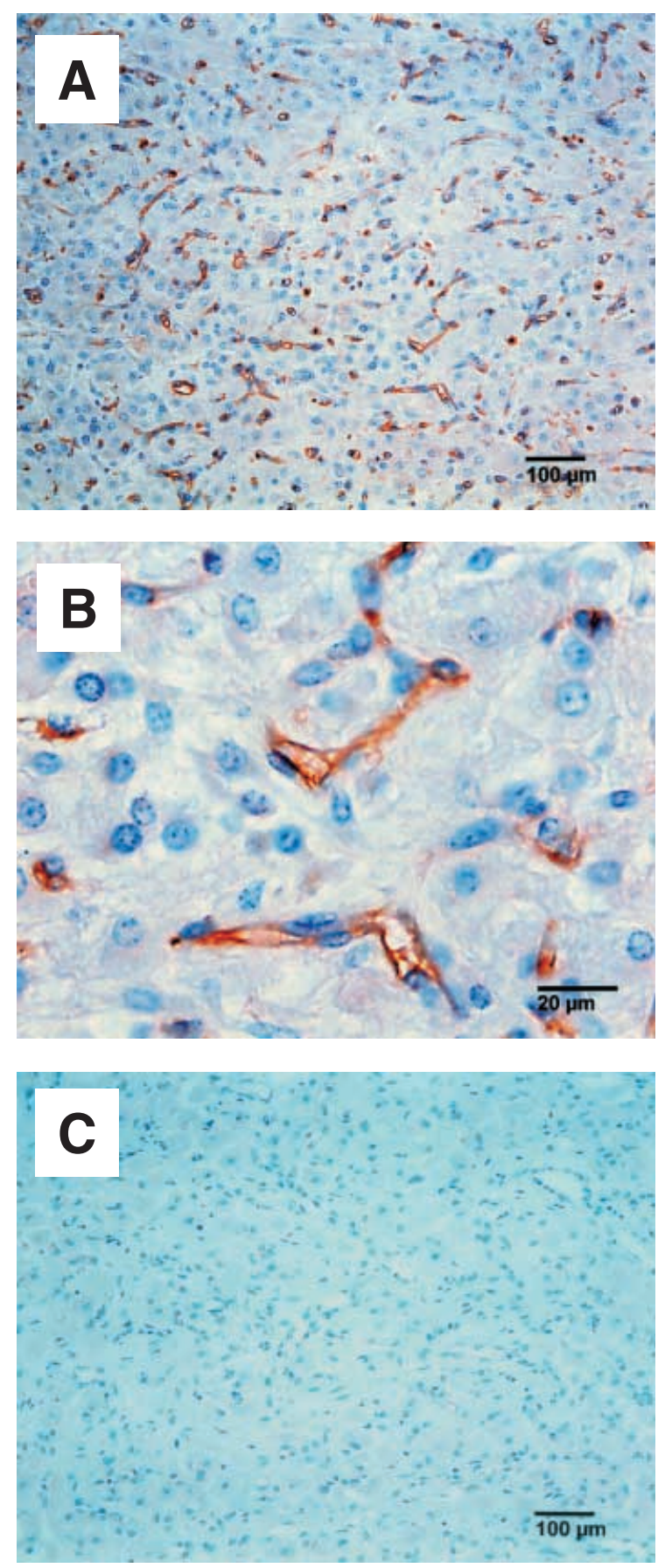

question as whether a cell-to-cell contact may be the requisite for a luteal response to bFGF. In this context, the present MDS study indicates Ang II and PGF2 $\alpha$ as the possible mediators of bFGF action on the progesterone secretion in early CL (Fig. 8).

The expression of mRNA for VEGF and the VEGF production in ovine (Redmer et al. 1996) and bovine (Schams et al. 1994, Berisha et al. 2000b) CL and in bovine luteinised granulosa cells (Garrido et al. 1993, Schams et al. 1999) have been described. On the other hand, the receptors for VEGF are expressed within CL not only during active angiogenesis, but also at similar levels in the midcycle CL (Goede et al. 1998). The VEGF secretion is stimulated by luteinising hormone (LH) and insulin-like growth factor-I as well as forskolin in bovine luteinised granulosa cells (Schams et al. 1999), suggesting that the main pathway depends on the cAMP activation. Thus, this study with granulosa cell culture indicated that the most potent stimulators for differentiation/luteinisation are also stimulators of VEGF secretion. This was also confirmed in another study, in which LH upregulates VEGF mRNA expression by ovine luteal cells in culture (Toutges et al. 1999). Consequently, it is most likely that luteinising granulosa cells secrete VEGF that accelerates early angiogenesis in the newly formed CL. In support of this idea, the treatment of marmoset monkey with gonadotrophinreleasing hormone antagonist (LH suppression) or anti-VEGF severely suppressed both endothelial cell proliferation in the CL and plasma progesterone levels (Fraser et al. 2000). Similarly, the treatment of rats with truncated soluble Flt-1 receptors, which inhibits VEGF bioactivity, resulted in virtually complete suppression of CL angiogenesis (Ferrara et al. 1998).

The present MDS study suggests that PGF2 $\alpha$ produced in early CL acts as a stimulator of progesterone and OT release within bovine early $\mathrm{CL}$, by cooperating with the vasoactive peptide Ang II (Fig. 8). Since PGF2 $\alpha$ was shown to affect progesterone secretion as a suppressor together with Ang II in bovine midcycle CL (Hayashi \& Miyamoto 1999), the opposite effects strongly suggest that the mechanism for interaction of PGF2 $\alpha$ with Ang II in early CL is quite different from that of the aged CL after the end of active angiogenesis. A higher production of PGF2 $\alpha$ in early CL than in other luteal phases has been reported (Milvae \& Hansel 1983, Rodgers et al. 1988). The present result also showed that concentrations of PGF2 $\alpha$ and Ang II in early CL in the MDS fractions were significantly higher than those of midcycle CL using the

Figure 2 Immunohistochemical localisation of ACE in bovine luteal tissue (2-3 days old). Positive staining for ACE was restricted to newly formed blood vessels (A). The immunostaining is localised to endothelial cells and higher magnification (B) demonstrates particular intense staining of the cell membrane.

(C) Replacement of the primary antibody with non-immune serum. $\operatorname{Bar}=100 \mu \mathrm{m}$ for $(\mathrm{A}), 20 \mu \mathrm{m}$ for $(\mathrm{B})$ and $100 \mu \mathrm{m}$ for $(\mathrm{C})$. 


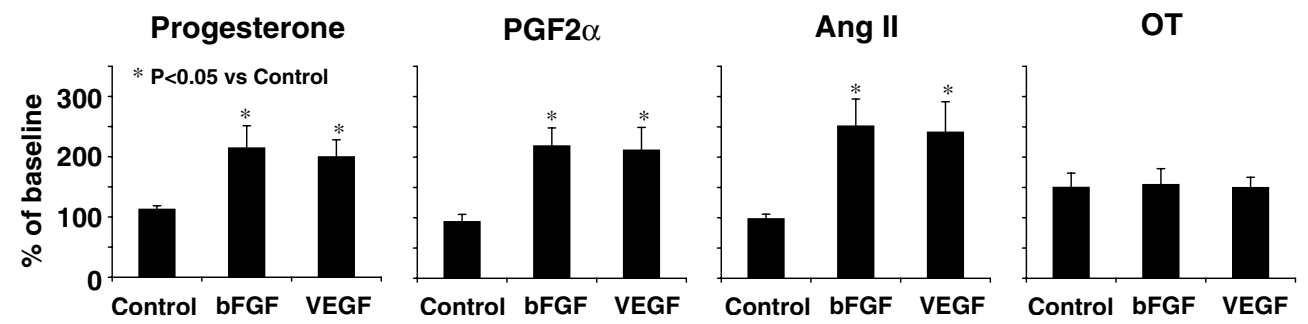

Figure 3 Effects of bFGF $(7 \cdot 5 \mathrm{nmol} / \mathrm{l})$ and VEGF $(5 \mathrm{nmol} / \mathrm{l})$ on progesterone, PGF2 $\alpha$, Ang II and OT release from microdialysed bovine early $\mathrm{CL}$ in vitro. Data are expressed as means \pm S.E.M. of the percentage of the basal release of each hormone during the infusion of growth factors for $2 \mathrm{~h}$ ( $n=8 \mathrm{CL} /$ group). Baseline concentrations $(100 \%)$ were $9 \cdot 5 \pm 1.0 \mathrm{nmol} / \mathrm{l}$ for progesterone, $14 \cdot 1 \pm 3.1 \mathrm{pmol} / \mathrm{l}$ for PGF2 $\alpha$, $5 \cdot 8 \pm 1 \cdot 9 \mathrm{pmol} / \mathrm{l}$ for Ang II and $5 \cdot 2 \pm 0 \cdot 6 \mathrm{pmol} / \mathrm{I}$ for OT.

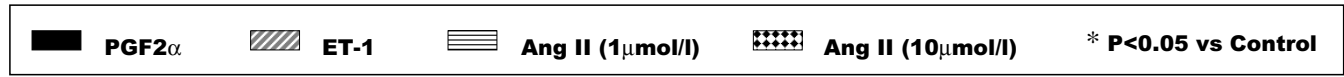

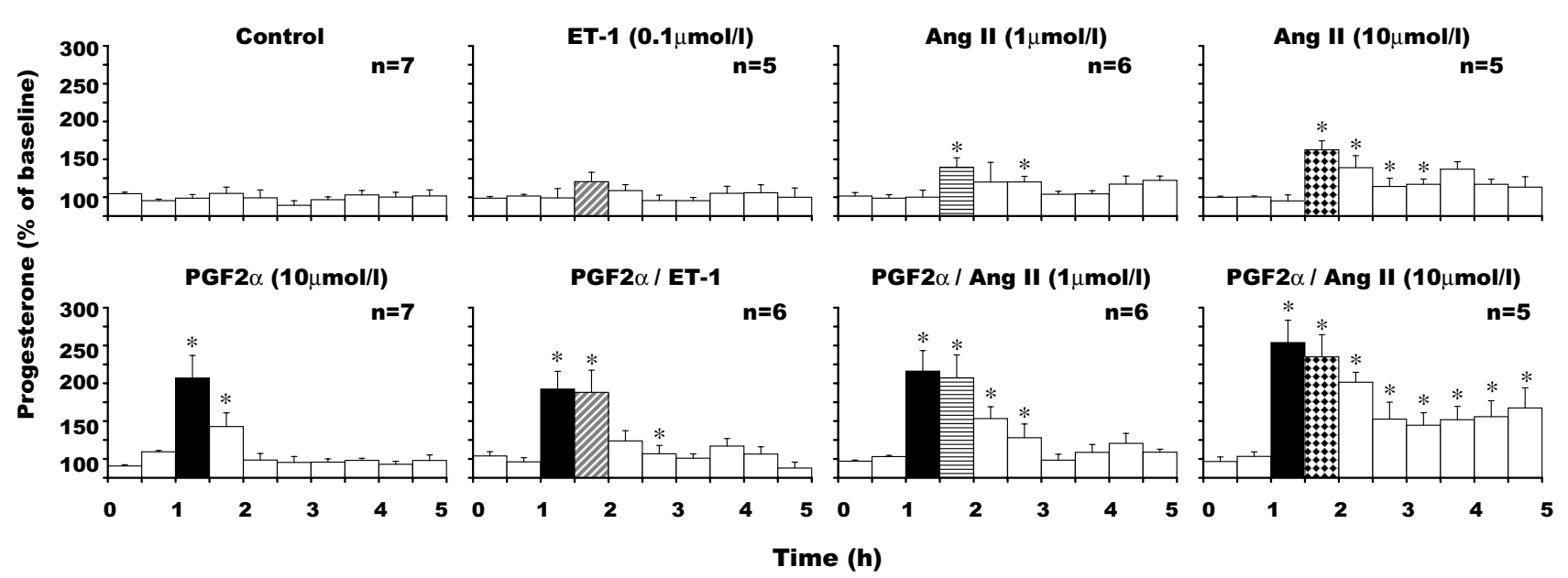

Figure 4 Interaction of Ang II (10 and $1 \mu \mathrm{mol} / \mathrm{l})$ or ET-1 $(0 \cdot 1 \mu \mathrm{mol} / \mathrm{l})$ and PGF2 $\alpha(10 \mu \mathrm{mol} / \mathrm{l})$ on progesterone release from microdialysed bovine early $\mathrm{CL}$ in vitro. Data are expressed as means \pm S.E.M. of the percentage of the basal release of each hormone $(n=5-7 \mathrm{CL} / \mathrm{group})$. Baseline concentration (100\%) was $25 \cdot 7 \pm 4 \cdot 4 \mathrm{nmol} / \mathrm{l}$ for progesterone.

same MDS model (early vs mid (Hayashi \& Miyamoto 1999): PGF2 $\alpha 29 \cdot 4$ vs $4 \cdot 2 \mathrm{pmol} / 1$, Ang II $8 \cdot 8$ vs $3 \cdot 7 \mathrm{pmol} /$ 1). On the other hand, the ET-1 concentration in early CL was extremely low $(0 \cdot 04$ vs $0 \cdot 84 \mathrm{pmol} / \mathrm{l})$. These differences may be related to the fact that a luteolytic injection of PGF2 $\alpha$ is not capable of inducing a full regression of the CL during the early luteal phase of the oestrous cycle.

The extracellular concentration of Ang II in the present result was calculated to be around $9.6 \mathrm{nmol} / 1$ if the concentration of Ang II in the perfusate and the transfer capacity of the MDS membrane are considered. This concentration is clearly much higher than that of plasma, which has been recently published (Acosta et al. 2000). The present result shows the existence of ACE in endothelial cells in bovine early CL. This implies that Ang II is converted from Ang I by ACE on the surface of endothelial cells in CL. This finding supports the concept that bovine early CL is a site of Ang II production. Recently, we found that mRNAs for angiotensin type 1 and 2 receptors were expressed in bovine CL, and the level of type 2 receptor mRNA in early CL was higher than that of midcycle CL (Hayashi et al. 2000). Thus, Ang II may act as a paracrine factor in luteal secretory function, in addition to its vasoactive action. Importantly, an infusion of Ang II stimulated progesterone and PGF2 $\alpha$ secretion from early CL, and PGF2 $\alpha$ also stimulated progesterone secretion in the present study (Fig. 8). PGF2 $\alpha$ has been repeatedly shown to stimulate progesterone secretion of bovine CL in vitro (Hixon \& Hansel 1979, Benhaim et al. 1987, Alila et al. 1988, Meidan et al. 1992, Miyamoto et al. 1993). A $30 \mathrm{~min}$ infusion of Ang II at $10 \mu \mathrm{mol} / 1$ following PGF2 $\alpha$ continued to stimulate progesterone release. This result in early CL was completely opposite to what we observed in midcycle CL using the same MDS model, 


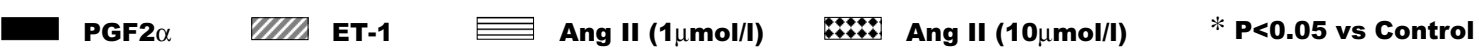

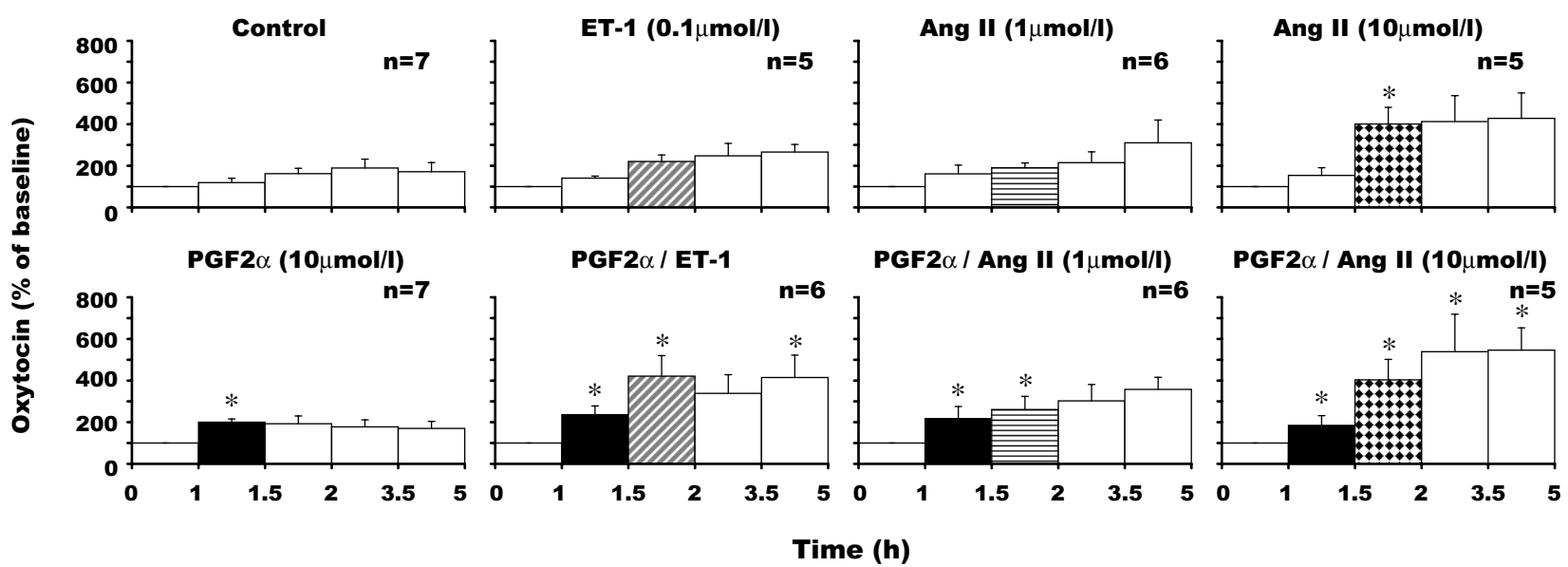

Figure 5 Interaction of Ang II (10 and $1 \mu \mathrm{mol} / \mathrm{l})$ or ET-1 $(0 \cdot 1 \mu \mathrm{mol} / \mathrm{l})$ and PGF2 $\alpha(10 \mu \mathrm{mol} / \mathrm{l})$ on OT release from microdialysed bovine early $\mathrm{CL}$ in vitro. Data are expressed as means \pm S.E.M. of the percentage of the basal release of each hormone $(n=5-7 \mathrm{CL} / \mathrm{group})$. Baseline concentration (100\%) was $4.9 \pm 0.7 \mathrm{pmol} / \mathrm{l}$ for OT.

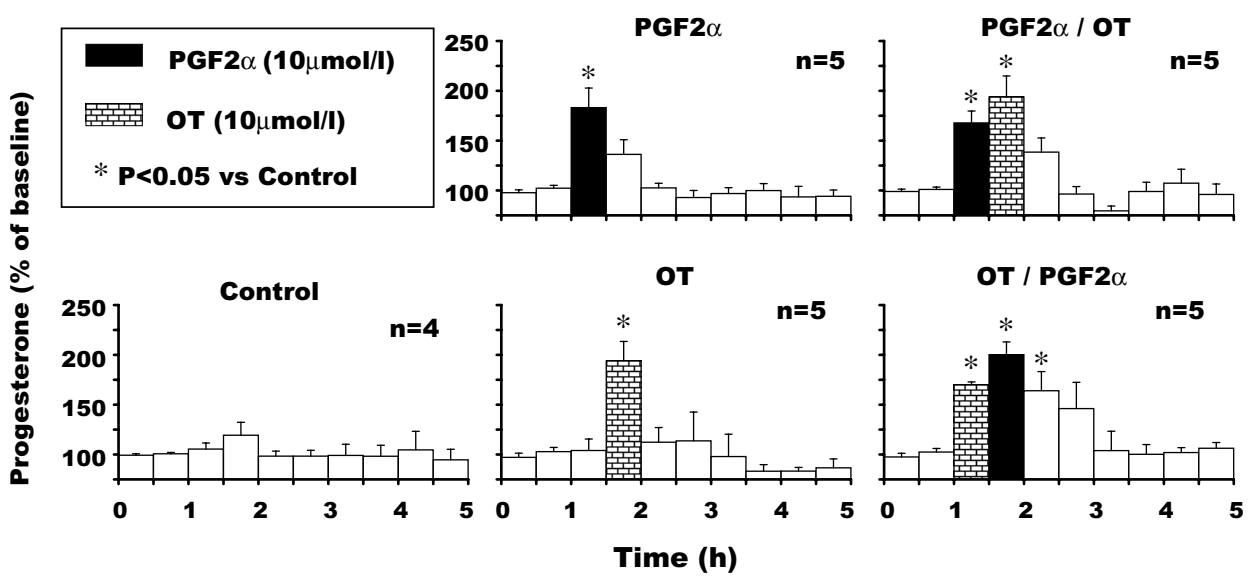

Figure 6 Interaction of OT $(10 \mu \mathrm{mol} / \mathrm{l})$ and PGF2 $\alpha(10 \mu \mathrm{mol} / \mathrm{l})$ on progesterone release from microdialysed bovine early $\mathrm{CL}$ in vitro. Data are expressed as means \pm S.E.M. of the percentage of the basal release of each hormone $(n=4-5 \mathrm{CL} /$ group). Baseline concentration (100\%) was $15 \cdot 2 \pm 1 \cdot 0 \mathrm{nmol} / \mathrm{l}$ for progesterone.

where Ang II fundamentally inhibited progesterone release and the inhibitory effect of Ang II was potentiated by the PGF2 $\alpha$ infusion (Hayashi \& Miyamoto 1999). As described above, the local Ang II concentration was also higher in early CL than in midcycle CL. Thus, these data emphasise that Ang II in high concentration acts predominantly via type 2 receptors in early CL, by which it supports the mechanism that regulates progesterone secretion.

Ang II induces neovascularisation in the eye of rabbit (Fernandez et al. 1985) and in endometrium of rat and human (Hu et al. 1996, Li \& Ahmed 1996, Walsh et al.
1997). Therefore, our study shows that Ang II not only stimulated angiogenesis itself, but also had an ability to augment progesterone secretion (Fig. 8). Several lines of evidence support this concept. Namely, Ang II upregulates the expression of mRNA for an angiogenic factor bFGF in bovine luteal cells (Stirling et al. 1990), and bFGF and VEGF enhance PGF2 $\alpha$ and Ang II production of bovine early CL in the present study. In fact, we recently found that bFGF and VEGF together with oestradiol-17 $\beta$ augment the Ang II production in endothelial cells derived from developing bovine CL (Hayashi et al. 2000). Likewise, bFGF increases prostaglandin $\mathrm{H}$ synthase activity 


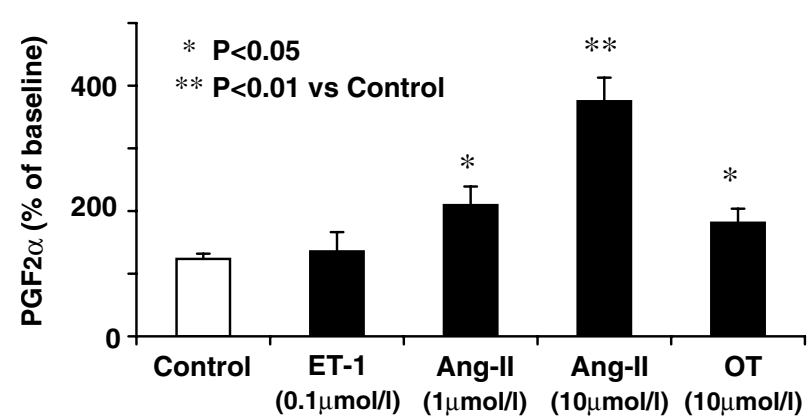

Figure 7 Effects of the luteal peptides on PGF2 $\alpha$ release from microdialysed bovine early $\mathrm{CL}$ during the infusion of substances. Data are expressed as percentages (means \pm S.E.M.) of the basal release of each hormone ( $n=5 \mathrm{CL}$ /group). The baseline $(100 \%)$ of PGF2 $\alpha$ was $7 \cdot 1 \pm 0 \cdot 8 \mathrm{pg} / \mathrm{ml}$.

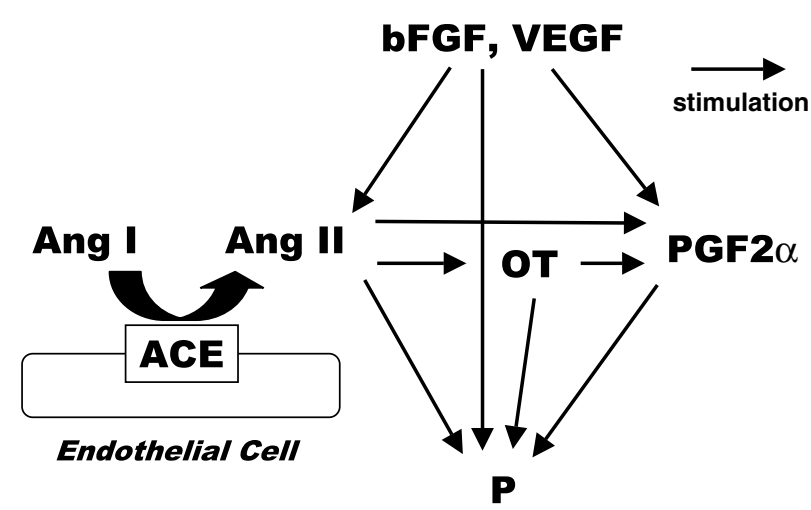

Figure 8 Schematic interrelationship among angiogenic growth factors, Ang II, PGF2 $\alpha$, OT and progesterone in bovine early $\mathrm{CL}$, based on the results obtained in microdialysed early $\mathrm{CL}$ in vitro.

(Rosenstock et al. 1997) and VEGF induces constitutive cyclooxygenase-1 expression (Bryant et al. 1998) in bovine endothelial cells. Indeed, the infusion of Ang II stimulated PGF2 $\alpha$ production in our MDS study. Therefore, the cause for the very high concentration of PGF2 $\alpha$ in early CL appears to be the result of active angiogenesis involving the action of Ang II, bFGF and VEGF (Fig. 8).

ET-1 is one of the major vasoactive 21-amino acid peptides that is synthesised and secreted from endothelial cells (Yanagisawa et al. 1988). Recent studies by our laboratory and by others have indicated that luteal ET-1 interacts with PGF2 $\alpha$ and have suggested that ET-1 plays an essential role in luteolysis in the cow (Girsh et al. 1996a, Miyamoto et al. 1997, Ohtani et al. 1998). In the present study, however, the infusion of ET-1 had no effect on progesterone release from early $\mathrm{CL}$ and also did not stimulate PGF2 $\alpha$ release. Importantly, the ET-1 concentration in the MDS purfusate of early CL in which neovascularisation is mostly active was about onetwentieth of the value in the midcycle CL as described above. This difference in the ET-1 concentrations in CL between the two luteal phases was similar to the result of
Girsh et al. (1996b). In fact, ET-1 was shown to have no effect on the stimulation of angiogenesis in the rat while Ang II stimulated neovascularisation ( $\mathrm{Hu}$ et al. 1996). However, another study has shown the stimulatory role of ET-1 in angiogenesis in rat kidney (Goligorsky et al. 1999). Thus, we can not exclude the possibility that ET-1 also has angiogenic activity in the early CL. Collectively, these findings suggest that ET-1 does not take part in the local mechanisms involved in angiogenesis and secretory function in the developing CL. Also, this may be one of the reasons why early CL before day 5 of the oestrous cycle are resistant to an injection of PGF2 $\alpha$.

It was suggested that a positive feedback of uterine PGF2 $\alpha$ and luteal OT is established during CL regression (Flint \& Scheldrick 1983, Schams et al. 1985). In the present study, the infusion of PGF2 $\alpha$ stimulated OT release in early CL, and likewise the infusion of OT stimulated PGF2 $\alpha$ release. This indicates that a local positive feedback between PGF2 $\alpha$ and OT may exist within bovine early CL. OT stimulates secretion of PGF2 $\alpha$ (Grazul et al. 1989, the present study) and progesterone (Miyamoto \& Schams 1991), and bovine luteal cells possess binding sites for OT (Okuda et al. 1992). In addition, a recent study has revealed that an OT antagonist, atosiban, inhibits PGF2 $\alpha$ and progesterone secretion from bovine luteal cells on days 3-5 of the oestrous cycle (Skarzynski \& Okuda 1999). These lines of evidence suggest that OT supports the mechanism that is responsible for PGF $2 \alpha$ and progesterone production within the developing CL. In the present study, interactions between PGF2 $\alpha$ and Ang II appeared to stimulate OT secretion, whereas the interaction of PGF2 $\alpha$ with ET-1 was very weak. The infusion of Ang II stimulated both PGF2 $\alpha$ and OT release from bovine early CL. Consequently, we hypothesise that Ang II further activates the positive feedback of PGF2 $\alpha$ and OT within the developing CL, and this effect ensures the mechanism of progesterone synthesis and secretion (Fig. 8).

In conclusion, the overall results of this study indicate that the functional angiotensin system exists on the endothelial cells of early CL, and that angiogenic factors bFGF and VEGF upregulate luteal Ang II and PGF2 $\alpha$ secretion, which fundamentally supports the mechanism of progesterone production in bovine early CL. This idea supports the concept that the local regulatory mechanism involved in active angiogenesis ensures the progesterone secretion in the developing CL in vivo.

\section{Acknowledgements}

The authors thank Dr K Okuda, Okayama University, for progesterone antiserum; Dr T Higuchi, Kochi University of Medicine, for OT antiserum; Dr S Ito, Kansai University of Medicine, for PGF2 $\alpha$ antiserum; Dr K Wakabayashi, Gunma University, for Ang II antiserum; 
and Fresenius AG, St Wendel, Germany, for the microdialysis capillary membrane. This study was supported by the German Research Foundation (Scha 257/14-1), Grant-in-Aid for Scientific Research (11660276 and 12556046) and the Japan-Germany joint research project of the Japan Society for the Promotion of Science, the Novartis Foundation (Japan) for the Promotion of Science, and the Morinaga Hoshikai Foundation.

\section{References}

Acosta TJ, Miyamoto A, Ozawa T, Wijayagunawardane MPB \& Sato K 1998 Local release of steroid hormones prostaglandin E2 and endothelin-1 from bovine mature follicles in vitro: effects of luteinizing hormone, endothelin-1, and cytokines. Biology of Reproduction 59 437-443.

Acosta TJ, Ozawa T, Kobayashi S, Hayashi K, Ohtani M, Kraetzl WD, Sato K, Schams D \& Miyamoto A 2000 Preovulatory changes in the local release of vasoactive peptides, prostaglandin F2 $\alpha$, and steroid hormones from bovine mature follicles in vivo. Biology of Reproduction 63 1253-1261.

Alila HW, Dowd JP, Corradino RA, Harris WV \& Hansel W 1988 Control of progesterone production in small and large bovine luteal cells separated by flow cytometry. Journal of Reproduction and Fertility 82 645-655.

Benhaim A, Bonnamy PJ, Papadopoulos V, Mittre H \& Leymarie P 1987 In vitro action of PGF $2 \alpha$ on progesterone and cAMP synthesis in small bovine luteal cells. Prostaglandins 33 227-239.

Berisha B, Schams D, Kosmann M, Amselgruber W \& Einspanier R $2000 a$ Expression and localisation of vascular endothelial growth factor and basic fibroblast growth factor during the final growth of bovine ovarian follicles. Journal of Endocrinology 167 371-382.

Berisha B, Schams D, Kosmann M, Amselgruber W \& Einspanier R $2000 \mathrm{~b}$ Expression and tissue concentration of vascular endothelial growth factor, its receptors, and localization in the bovine corpus luteum during estrous cycle and pregnancy. Biology of Reproduction 63 1106-1114.

Bryant CE, Appleton I \& Mitchell JA 1998 Vascular endothelial growth factor upregulates constitutive cyclooxygenase 1 in primary bovine and human endothelial cells. Life Science 62 2195-2201.

Chomczynski P \& Sacchi N 1987 Single-step method of RNA isolation by acid guanidinium thiocyanate-phenol-chloroform extraction. Analytical Biochemistry 162 156-159.

Fernandez LA, Twickler J \& Mead A 1985 Neovascularization produced by angiotensin II. Journal of Laboratory and Clinical Medicine 105 141-145.

Ferrara N \& Davis-Smyth T 1997 The biology of vascular endothelial growth factor. Endocrine Reviews 18 4-25.

Ferrara N, Chen H, Davis-Smyth T, Gerber HP, Nguyen TN, Peers D, Chisholm V, Hillan KJ \& Schwall RH 1998 Vascular endothelial growth factor is essential for corpus luteum angiogenesis. Nature Medicine 4 336-340.

Flint APF \& Sheldrick EL 1983 Evidence for a systemic role for ovarian oxytocin in luteal regression in sheep. Journal of Reproduction and Fertility $67215-225$.

Fraser HM, Dickson SE, Lunn SF, Wulff C, Morris KD, Carroll VA \& Bicknell R 2000 Suppression of luteal angiogenesis in the primate after neutralization of vascular endothelial growth factor. Endocrinology 141 995-1000.

Garrido C, Saule S \& Gospodarowicz D 1993 Transcriptional regulation of vascular endothelial growth factor gene expression in ovarian bovine granulosa cells. Growth Factors 8 109-117.

Girsh E, Milvae RA, Wang W \& Meidan R 1996a Effect of endothelin-1 on bovine luteal cell function: role in prostaglandin F2 $\alpha$-induced antisteroidogenic action. Endocrinology 137 1306-1312.
Girsh E, Wang W, Mamluk R, Arditi F, Freidman A, Milvae RA \& Meidan R 1996 Regulation of endothelin-1 expression in the bovine corpus luteum: elevation by prostaglandin F2 $\alpha$. Endocrinology 137 5191-5196.

Goede V, Schmidt T, Kimmina S, Kozian D \& Augstin HG 1998 Analysis of blood vessel maturation processes during cyclic ovarian angiogenesis. Laboratory Investigation 78 1385-1394.

Goligorsky MS, Budzikowski AS, Tsukahara H \& Noiri E 1999 Co-operation between endothelin and nitric oxide in promoting endothelial cell migration and angiogenesis. Clinical and Experimental Pharmacology and Physiology 26 269-271.

Gospodarowicz D, Cheng J, Lui GM, Baird A, Esch F \& Bohlen P 1985 Corpus luteum angiogenic factor is related to fibroblast growth factor. Endocrinology 117 2383-2391.

Gospodarowicz D, Neufeld G \& Schweigerer L 1986 Molecular and biological characterization of fibroblast growth factor, an angiogenic factor which also controls the proliferation and differentiation of mesoderm and neuroectoderm derived cells. Cell Differentiation 19 $1-17$.

Grazul AT, Kirsch JD, Slanger WD, Marchello MJ \& Redmer DA 1989 Prostaglandin F2 $\alpha$, oxytocin and progesterone secretion by bovine luteal cells at several stages of luteal development: effects of oxytocin, luteinizing hormone, prostaglandin F $2 \alpha$ and estradiol-17 $\beta$. Prostaglandins 38 307-318.

Grazul-Bilska AT, Redmer DA, Killilea SD, Kraft KC \& Reynolds LP 1992 Production of mitogenic factor(s) by ovine corpora lutea throughout the estrous cycle. Endocrinology 130 3625-3632.

Hayashi K \& Miyamoto A 1999 Angiotensin II interacts with prostaglandin F2 $\alpha$ and endothelin-1 as a local luteolytic factor in the bovine corpus luteum in vitro. Biology of Reproduction 60 1104-1109.

Hayashi K, Miyamoto A, Berisha B, Kosmann MR, Okuda K \& Schams D 2000 Regulation of angiotensin II production and angiotensin receptors in microvascular endothelial cells from bovine corpus luteum. Biology of Reproduction 62 162-167.

Hixon JE \& Hansel W 1979 Effects of prostaglandin F2 $\alpha$, estradiol and luteinizing hormone in dispersed cell preparations of bovine corpora lutea. In Ovarian Follicular and Corpus Luteum Function, pp 613-619. Eds CP Channing, JM Marsh \& WA Sadler. New York: Plenum.

Hsu SM, Raine L \& Fanger H 1981 Use of avidin-biotin-peroxidase complex $(\mathrm{ABC})$ in immunoperoxidase techniques: a comparison between $\mathrm{ABC}$ and unlabeled antibody (PAP) procedures. Journal of Histochemistry and Cytochemistry 29 577-580.

Hu DE, Hiley CR \& Fan TP 1996 Comparative studies of angiogenic activity of vasoactive intestinal peptide, endothelin- 1 and -3 and angiotensin II in a rat sponge model. British Journal of Pharmacology 117 545-551.

Ideishi M, Noda K, Sasaguri M, Ikeda M \& Arakawa K 1993 Angiotensin II forming activity of vascular endothelial and smooth muscle cells. Artery 20 95-102.

Ireland JJ, Murphee RL \& Coulson PB 1980 Accuracy of predicting stages of bovine estrous cycle by gross appearance of corpus luteum. Journal of Dairy Science 63 155-160.

Jarry H, Einspanier A, Kanngiesser L, Dietrich M, Pitzel L, Holtz W \& Wuttke W 1990 Release and effects of oxytocin on estradiol and progesterone secretion in porcine corpora lutea as measured by an in vivo microdialysis system. Endocrinology 126 2350-2358.

Kuo TC, Endo K, Dharmarajan AM, Miyazaki T, Atlas SJ \& Wallach EE 1991 Direct effect of angiotensin II on in vitro perfused rabbit ovary. Journal of Reproduction and Fertility 92 469-474.

Li XF \& Ahmed A 1996 Dual role of angiotensin II in the human endometrium. Human Reproduction 11 (Suppl 2) 95-108.

Meidan R, Aberdam E \& Aflalo L 1992 Steroidogenic enzyme content and progesterone induction by cyclic adenosine $3^{\prime}, 5^{\prime}$ monophosphate-generating agents and prostaglandin F2 $\alpha$ in bovine theca and granulosa cells luteinized in vitro. Biology of Reproduction $46786-792$. 
Milvae RA \& Hansel W 1983 Prostacyclin, prostaglandin F2 $\alpha$ and progesterone production by bovine luteal cells during the estrous cycle. Biology of Reproduction 29 1063-1068.

Miyamoto A \& Schams D 1991 Oxytocin stimulates progesterone release from microdialyzed bovine corpus luteum in vitro. Biology of Reproduction 44 1163-1170.

Miyamoto A, Okuda K, Schweigert FJ \& Schams D 1992 Effects of basic fibroblast growth factor, transforming growth factor- $\beta$ and nerve growth factor on the secretory function of the bovine corpus luteum in vitro. Journal of Endocrinology 135 103-114.

Miyamoto A, von Lützow H \& Schams D 1993 Acute action of prostaglandin $\mathrm{F} 2 \alpha, \mathrm{E} 2$, and $\mathrm{I} 2$ in microdialyzed bovine corpus luteum in vitro. Biology of Reproduction 49 423-430.

Miyamoto A, Tashiro Y, Nakatsuka T, Meyer HHD, Taguchi K, Abe $N$ \& Fukui Y 1995 Effect of tumor necrosis factor- $\alpha$ and interleukin- 1 on local release of progesterone, prostaglandin F2 $\alpha$ and oxytocin in microdialyzed ovine corpus luteum in vitro. Assisted Reproductive Technology and Andrology 8 21-32.

Miyamoto A, Kobayashi S, Arata S, Ohtani M, Fukui Y \& Schams D 1997 Prostaglandin F2 $\alpha$ promotes the inhibitory action of endothelin-1 on the bovine luteal function in vitro. Journal of Endocrinology 152 R7-R11.

Ohtani M, Kobayashi S, Miyamoto A, Hayashi K \& Fukui Y 1998 Real-time relationships between intraluteal and plasma concentrations of endothelin, oxytocin, and progesterone during prostaglandin F2 $\alpha$-induced luteolysis in the cow. Biology of Reproduction 58 103-108.

Okuda K, Miyamoto A, Sauerwein H, Schweigert FJ \& Schams D 1992 Evidence for oxytocin receptors in cultured bovine luteal cells. Biology of Reproduction 46 1001-1006.

Okuda K, Sakumoto R, Uenoyama Y, Berisha B, Miyamoto A \& Schams D 1999 Tumor necrosis factor $\alpha$ receptors in microvascular endothelial cells from bovine corpus luteum. Biology of Reproduction 61 1017-1022.

Redmer DA, Dai Y, Li J, Charnock-Jones DS, Smith SK, Reynolds LP \& Moor RM 1996 Characterization and expression of vascular endothelial growth factor (VEGF) in the ovine corpus luteum. Journal of Reproduction and Fertility 108 157-165.

Rodgers RJ, Mitchell MD \& Simpson ER 1988 Secretion of progesterone and prostaglandins by cells of bovine corpora lutea from three stages of the luteal phase. Journal of Endocrinology 118 121-126.

Rosenstock M, Danon A \& Rimon G 1997 Prostaglandin H synthase: protein synthesis-independent regulation in bovine aortic endothelial cells. American Journal of Physiology 273 1749-1755.

Sakumoto R, Ando Y \& Okuda K 1996 Progesterone release of bovine corpus luteum in response to oxytocin in different culture systems. Journal of Reproduction and Development 42 199-204.

Schams D, Schallenberger E, Meyer HHD, Bullermann B, Breitinger H-J, Enzenhöfer G, Koll R, Kruip TAM, Walters DL \& Karg H 1985 Ovarian oxytocin during the estrous cycle in cattle. In
Oxytocin, Clinical and Laboratory Studies, pp 317-334. Eds JA Amico \& AG Robinson. Amsterdam: Elsevier Biomedical.

Schams D, Miyamoto A, Brückmann A, Sauerwein H, Amselgruber W, Sinowatz F \& Gospodarowicz D 1993 Basic growth factor and luteal function (location, binding and stimulation of secretion). Biology of Reproduction 48 (Suppl 1) abstract 14.

Schams D, Amselgruber W, Einspanier R, Sinowatz F \& Gospodarowicz D 1994 Localization and tissue concentration of basic fibroblast growth factor in the bovine corpus luteum. Endocrine 2 907-912.

Schams D, Schmidt K \& Schlegel W 1995 Effects of growth factors on prostaglandin secretion of bovine luteal cells in vitro at different stages of the luteal phase. Biology of Reproduction 53 (Suppl 1) abstract 569 .

Schams D, Kosmann M, Berisha B \& Miyamoto A 1999 Stimulation of vascular endothelial growth factor (VEGF) in cultured bovine granulosa-luteal cells. Biology of Reproduction 60 (Suppl 1) abstract 462 .

Skarzynski DJ \& Okuda K 1999 Sensitivity of bovine corpora lutea to prostaglandin F2 $\alpha$ is dependent on progesterone, oxytocin, and prostaglandins. Biology of Reproduction 60 1292-1298.

Stirling D, Magness RR, Stone R, Waterman MR \& Simpson ER 1990 Angiotensin II inhibits luteinizing hormone-stimulated cholesterol side chain cleavage expression and stimulates basic fibroblast growth factor expression in bovine luteal cells in primary culture. Journal of Biological Chemistry 265 5-8.

Stirling D, Waterman MR \& Simpson ER 1991 Expression of mRNA encoding basic fibroblast growth factor (bFGF) in bovine corpora lutea and cultured luteal cells. Journal of Reproduction and Fertility 91 1-8.

Tallant EA, Lu X, Weiss RB, Chappell MC \& Ferrario CM 1997 Bovine aortic endothelial cells contain an angiotensin-(1-7) receptor. Hypertension 29 388-393.

Toutges MJ, Grazul-Bilska AT, Kirsch JD, Reynolds LP \& Redmer DA 1999 Effects of luteinizing hormone $(\mathrm{LH})$ and oxygen $\left(\mathrm{O}_{2}\right)$ levels on vascular endothelial growth factor (VEGF) mRNA expression by ovine luteal cells in culture. Biology of Reproduction $\mathbf{6 0}$ (Suppl 1) abstract 601.

Walsh DA, Hu DE, Wharton J, Catravas JD, Blake DR \& Fan TP 1997 Sequential development of angiotensin receptors and angiotensin I converting enzyme during angiogenesis in the rat subcutaneous sponge granuloma. British Journal of Pharmacology 120 1302-1311.

Yanagisawa M, Kurihara H, Kimura S, Tomobe Y, Kobayashi M, Mitui Y, Yazaki Y, Goto K \& Masaki T 1988 A novel potent vasoconstrictor peptide produced by vascular endothelial cells. Nature 332 411-415.

Yoshimura Y, Karube M, Oda T, Koyama N, Shinokawa S, Akiba M, Yoshinaga A \& Nakamura Y 1993 Locally produced angiotensin II induces ovulation by stimulating prostaglandin production in in vitro perfused rabbit ovaries. Endocrinology 133 1609-1616.

Received in final form 18 April 2001

Accepted 24 April 2001 